\title{
Movements between microhabitats depending on reproduction and life history in the sand-bubbler crab Scopimera globosa
}

\author{
T. Koga \\ Laboratory of Ecology, Department of Biology, Faculty of Science, Kyushu University, Hakozaki, Fukuoka 812, Japan
}

\begin{abstract}
Sand-bubbler crabs Scopimera globosa inhabit burrows in the upper tidal sand flat and form droves in the water-saturated area of the lower tidal flat. To elucidate the function of the movements between the microhabitats in this species, I investigated the change in population density, crab body size and reproductive conditions of both sexes within each microhabitat. Ovigerous females were found in the burrow area while spent females (releasing zoea recently) were concentrated in the watersaturated area. Gonad weights of nonovigerous females in the burrow area were higher than those in the water-saturated area. Both male and female crabs in the water-saturated area, where diet quality (organic nitrogen content of the surface substratum) exceeded that in the burrow area, spent more time foraging and suffered less from interactions with neighbours than crabs in the burrow area. In contrast, although both gonad and hepatopancreas weights of males decreased with time in the early to mid reproductive season, there was no difference in male body condition between microhabitats. Few crabs moved between the microhabitats in the mid to late reproductive season, indicating that most crabs active in the water-saturated area during low tides did not return to the burrow area during high tides, differing from the movements of other ocypodid species. S. globosa have alternative mating behaviours, underground copulation (UC) and surface copulation (SC). UC, followed by oviposition, was dominant in the burrow area, though both UC and SC were conducted there. In contrast, SC, not always followed by oviposition, was dominant in the water-saturated area. Females maximized their use of the microhabitats, i.e. the burrow area for mating, oviposition and incubation and the watersaturated area for foraging and partly for mating. The operational sex ratio was biased towards males in the burrow area and towards females in the water-saturated area, due to the fact that the last male to mate fertilizes most of the eggs extruded by a female. A high proportion of large (i.e. older) crabs of both sexes stayed in the burrow area during the reproductive season, whereas small (young) crabs spent most of their time in the water-saturated area for growth. Thus, the crabs made suitable use of their time in different microhabitats under a life history strategy.
\end{abstract}

KEY WORDS: Sand-bubbler crab - Microhabitat use - Burrow area - Water-saturated area - Reproduction - Life history

\section{INTRODUCTION}

The sand-bubbler crab Scopimera globosa inhabits burrows in the upper tidal sand flat and forms droves in the water-saturated area of the lower tidal flat (Sugiyama 1961, Ono 1965, Yamaguchi \& Tanaka 1974) similar to other ocypodid crabs such as Macrophthalmus japonicus (Henmi 1984, 1989a), Uca pugilator (Salmon \& Hyatt 1983, Christy \& Salmon 1984) and $U$. vocans (Murai et al. 1983, Nakasone et al. 1983). In these species, the crabs mainly forage in the water- saturated area, whereas they copulate and extrude eggs in the burrow area (but $U$. vocans also copulates frequently in the water-saturated area). In $M$. japonicus and $U$. vocans, crabs in droves near the water's edge during low tides stay in the burrow area during high tides (Nakasone et al. 1983, Henmi 1989a). Yamaguchi \& Tanaka (1974) and Wada (1981b) reported that $S$. globosa in the burrow area moved to the watersaturated area after emersion of the substrate and returned when tides came in, as seen in $M$. japonicus and $U$. vocans. However, in order to ascertain whether 
droves of $S$. globosa also remain in the water-saturated areas even during high tides, I directly observed the movement pattern of $S$. globosa.

Three possible explanations exist for the formation of droves in the water-saturated area in Scopimera globosa. The first possibility is the interactions between individuals due to overcrowding in the burrow area ('social interaction hypothesis'; Sugiyama 1961, Ono 1965, Yamaguchi \& Tanaka 1974). When population density in the burrow area is high, crabs losing in combats there may move to the water-saturated area. Because competitive ability depends partly on body size, small crabs may be excluded from the burrow area while large ones remain there. In contrast, small crabs, as well as large ones, may remain in the burrow area when population density of the burrow area is low because competition pressure is relaxed. Thus, the difference in the body size of crabs between the burrow and water-saturated areas may be large when population density in the burrow area is high, whereas the difference may be small when the density is low.

A second possibility is associated with water condition (dryness) on the substrate surface ('water condition hypothesis'; Wada 1981b). Population density of crabs in the water-saturated area may be highest when the surface substrate of the burrow area is driest. In southwestern Japan (where June to mid July is the rainy season), the population density in the watersaturated area is typically highest in late July to August, the period with the highest intensity of sunlight and highest temperatures during the year.

A third possibility is the high foraging demand associated with the low energy reserves resulting from reproductive activities ('energy requirement hypothesis'; Iwata et al. 1983, Henmi et al. 1993). If the microhabitats of Scopimera globosa are divided into the sites for reproduction and for foraging similar to those of Uca vocans (see Murai et al. 1982 for a different nitrogen content in surface substrate between the microhabitats), the population density before the reproductive season may be high in the foraging site. During the reproductive season, population density may become high in the reproduction site where females oviposit and incubate. After investing energy in reproduction, crabs may move to the foraging site to accumulate energy for the next reproductive season. Energy reserves and female gonadal condition of $S$. globosa in the burrow area were different from those near the low tide line (Iwata et al. 1983, Henmi et al. 1993); however, it is not conclusive because integrated data were lacking. Life history theory predicts that iteroparous species should generally increase their yearling reproductive effort with age (reviewed in Andersson 1994). Small individuals may invest more resources in growth than in reproduction, while large individuals may invest more in reproduction than growth. Since the lifespan of $S$. globosa is about $2 \mathrm{yr}$, the crabs experience 2 reproductive seasons (see Henmi \& Kaneto 1989). Thus, young small crabs, which should allocate their energy to growth rather than reproduction, may stay longer in the foraging site than older, large crabs. In contrast, large crabs, which should allocate most of their energy to reproduction, may stay in the reproduction site for as long as possible.

To determine which of the 3 explanations is more likely, I show the differences between population density, body size and gonadal weight for both sexes of Scopimera globosa in the burrow and water-saturated areas. I also compare the behaviours and diet quality of crabs in the 2 microhabitats. I also suggest a reproductive and life history strategy for this species.

\section{METHODS}

Population sampling. The study site was a sandymuddy tidal flat at Wajiro Beach, Fukuoka, Japan $\left(33^{\circ} 36^{\prime} \mathrm{N}, 130^{\circ} 24^{\prime} \mathrm{E}\right)$. On a monthly or twice-a-month basis, I sampled a population of the crabs at 6 to 13 sites $\left(25 \times 25 \mathrm{~cm}^{2}\right.$ each) in the burrow and water-saturated areas near the median time of low tide periods from April to September 1992. All samplings were carried out in mid tides before spring tides, e.g. every second mid tide from May to September. I carefully excavated the sandy substrate to $20 \mathrm{~cm}$ depth in the burrow area and to $5 \mathrm{~cm}$ in the water-saturated area, and captured all crabs ( $>5.2 \mathrm{~mm}$ of carapace width). The burrow area is exposed for 8 to $10 \mathrm{~h}$ during each low tide period and nearly dries out within the first few hours of exposure on a sunny day. The watersaturated area is exposed for 6 to $7 \mathrm{~h}$ and rarely dries out during low tides. The tide level in the burrow area was approximately $20 \mathrm{~cm}$ higher than that in the water-saturated area. The reproductive period was from June to August.

Crabs were taken to the laboratory, where the carapace width was measured to the nearest $0.1 \mathrm{~mm}$ using a hand caliper, and sex and presence of eggs were recorded. Most crabs were then released back into the study area. Crabs of this species continue to grow during their lifetime (see Wada 1981a). Crabs of both sexes with $5.3 \mathrm{~mm}$ or larger carapace width were defined as mature, based on the size of the smallest ovigerous females of captured crabs $(5.3 \mathrm{~mm})$. Only these mature crabs were sampled and used for the analysis. Nonovigerous females were categorized as 'spent' or 'nonspent' by the condition of pleopods. The pleopods of nonspent females were clear and visible, while those of spent females were not visible due to a bundle of attachment stalks by which eggs had 
attached to the pleopods. The pleopods of spent females do not recover until next molting (pers. obs.). The operational sex ratio was defined as the ratio of the number of males to the number of males + nonovigerous females, because ovigerous females were not receptive to mating (pers. obs.).

Conditions of gonads or hepatopancreas. The conditions of gonads for both sexes and hepatopancreas in males were measured at each site and date. Males, collected in the burrow and water-saturated areas from May to early August, were dissected (10 males at each site and date, 120 males in total). Forty-one nonovigerous, nonspent females in the burrow area and 43 nonovigerous, nonspent females in the water-saturated area were dissected. These females were classified into 3 groups depending on the period of collection as follows: (1) the early reproductive season (early June); (2) the mid reproductive season (late June to late July); and (3) the late reproductive season (August). Some females extrude eggs twice a year. Groups 1 and 2 included females incubating the first broods and Group 3 the second ones (see Henmi \& Kaneto 1989). Gonads for both sexes and hepatopancreas for males were individually weighed after drying all tissues at $60^{\circ} \mathrm{C}$ for $48 \mathrm{~h}$. Relative ovary weight (ROW), gonadal weight (RGW) and hepatopancreas weight (RHW), each relative to dry body weight, were calculated for each crab. Thirty spent females were also dissected to show unripeness of their gonads.

Movements of crabs between the burrow and water-saturated areas. To determine whether crabs active in the water-saturated area during low tides remained there or moved to the burrow area during high tides, movement patterns of the crabs between both microhabitats were directly observed during July and August 1993. Observations were made for the lower site within the burrow area, the border between the burrow and water-saturated areas, and the upper site within the water-saturated area. The number of crabs crossing a line of $50 \mathrm{~cm}$ length, placed in each area parallel to the tide line, was counted for $10 \mathrm{~min}$ approximately 1 to $2 \mathrm{~h}$ after emersion of the areas and 1 to $2 \mathrm{~h}$ before the tidal inundation. The movements were categorized into 'along tides' and 'against tides' at ebb and flood tides. Crabs moved 'along tides' if they moved to the burrow area during high tides and left the burrow area for the water-saturated area after tides receded. Thus, the movement of crabs along tides would be observed in the burrow area. In contrast, if they stay in the water-saturated area during high tides, the movement of crabs along tides would not be observed in the burrow area, even when it is observed in other lower sites. Movements between these areas also occurred at the beginning of heavy rains and on a sunny day following heavy rains the previous night.
These movements associated with rain were counted, as described above, on 4 and 1 occasions, respectively.

Time budget of behaviours. The time budget of crab behaviours was compared between crabs in the burrow and water-saturated areas for both sexes. During daytime low tides from June to August 1993, burrowholding and burrowless crabs for both sexes were observed for $10 \mathrm{~min}$ and their various activities, timed to the nearest second, were recorded. Burrow-holding crabs were observed in the burrow area and burrowless ones were observed in the burrow and water-saturated areas. All females observed were nonovigerous. Ovigerous ones stayed in the burrows and seldom appeared above ground (see Henmi \& Kaneto 1989).

Mating behaviours. Scopimera globosa can engage in 2 kinds of mating behaviour, mating on the surface substrate (surface copulation, SC) or underground (underground copulation, UC) (Yamaguchi et al. 1979, Henmi et al. 1993). Yamaguchi et al. (1979) reported that UC occurs in the burrow area and SC in the watersaturated area. To ascertain this trend in my study site, both types of mating behaviour observed were enumerated for the burrow and water-saturated areas during daytime low tides in areas of 4 to $6 \mathrm{~m}^{2}$ from June to August 1993. UC was not visually observed because it was performed in the plugged burrow. Pairing underground, not UC, was observed in the field. However, since the insemination after pairing in the burrows was ascertained in this species (Koga et al. 1993), the underground pairings observed here were regarded as UC. The observation time was 43.8 and $14.9 \mathrm{~h}$ in the burrow and water-saturated areas, respectively.

Diet quality. The quality of diet was compared for crabs in the burrow and water-saturated areas. The surface substratum (1 $\mathrm{mm}$ depth) was collected monthly at random in the burrow and water-saturated areas from June to August 1993. The organic nitrogen content (see Ono 1965, Henmi 1984) was measured using an elemental analyzer (Yanagimoto Co., Ltd, Model MT-600). The sampling was carried out just after emersion in each area. The samples were dried at $60^{\circ} \mathrm{C}$ for $48 \mathrm{~h}$ before analysis.

\section{RESULTS}

\section{Changes in population densities}

Reproductive season was considered to be June to August, because the density of ovigerous females began to increase in early June, reached a peak in late June, and mostly disappeared in September (Fig. 1a). Most ovigerous females were found in the burrow area. From late June to late August, except late July, more than $80 \%$ of females were ovigerous in the burrow area. In 
(a)

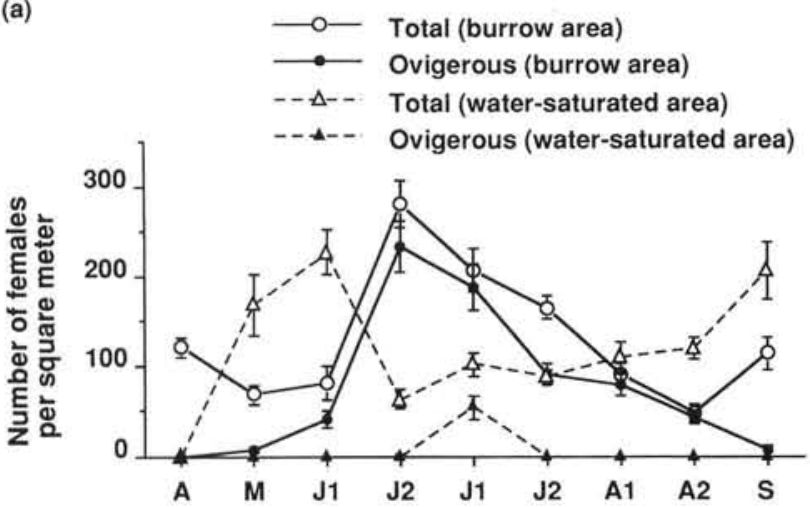

(b)

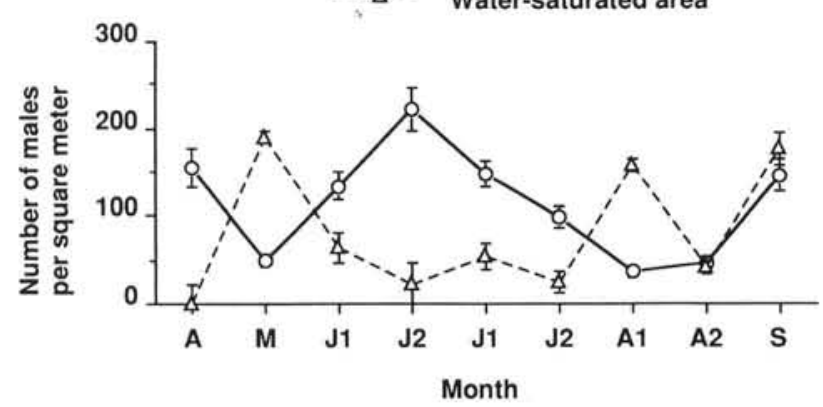

Fig. 1. Scopimera globosa. Seasonal changes of crab densities in the burrow and water-saturated areas for (a) females and (b) males. Vertical bars show standard errors. Number of sampling sites in the burrow and water-saturated areas was 9 and 6 in April (A in the figure), 9 and 9 in May (M), 10 and 6 in early June (J1), 7 and 13 in late June (J2), 8 and 10 in early July (J1), 10 and 13 in late July (J2), 12 and 9 in early August (A1), 13 and 11 in late August (A2), and 8 and 8 in September (S), respectively

late July, 26 out of 45 nonovigerous females paired underground with male mates in the burrow area. Within a few days after the late July sampling date, the ratio of ovigerous females to total females was estimated to be over $80 \%$ because most females which paired underground would have extruded eggs.

The population density of crabs varied drastically for both sexes in the burrow and water-saturated areas (Fig. 1a, b). Male and female densities in the watersaturated area were the highest in May and early June, respectively, not in late July and August. The temporal density of males and females changed similarly (Fig. 1). Many crabs of both sexes were in the watersaturated area before and at the beginning of the reproductive season. Population density for both sexes in the burrow area reached a maximum in late June and then gradually decreased with time. The increase in crab number seen in September was due to the growth of the crabs born in that year.

\section{Movement patterns of crabs}

The average number of crabs which moved to the lower site after emersion of the water-saturated areas or landwards before rising tides, i.e. the number of crabs moving 'along tides', was significantly different among the areas during the mid to late reproductive season $(F=8.23, \mathrm{df}=2, \mathrm{n}=33, \mathrm{p}<0.005$, ANOVA; Fig. 2). However, the number of crabs which moved to the burrow area after emersion of the water-saturated area and which moved to lower sites with a flooding tide, i.e. the number of crabs moving 'against tides', was not significantly different in the 3 areas $(F=0.54$, $\mathrm{df}=2, \mathrm{n}=33, \mathrm{p}>0.5$; Fig. 2). That is, the number of moving crabs was consequently smaller in the burrow area than in the border area of the burrow and watersaturated areas or the water-saturated area, although crabs at the lower edge of the burrow area or the water-saturated area moved to the lower site after emersion of the areas and the crabs moved landwards before the flood tide (Fig. 2). Thus, most crabs active in the water-saturated area during low tides remained in the border area of the 2 microhabitats or the watersaturated area, not in the burrow area, even during high tides. Relatively more females moved between the microhabitats than males in July and August (Fig. 1).

However, when it began to rain intensely, many crabs moved from the border area of the burrow and water-saturated areas to the burrow area (mean $\pm \mathrm{SD}=$ $54.3 \pm 62.9, \mathrm{n}=4$ ), where the number of moving crabs was greater than that under other conditions in the burrow area $(5.8 \pm 14.8, \mathrm{n}=24$; i.e. moving crabs along tides + those against tides of 'B' in Fig. 2) $(t=3.52$, p < $0.005, t$-test). The crabs returned to the water-satu-

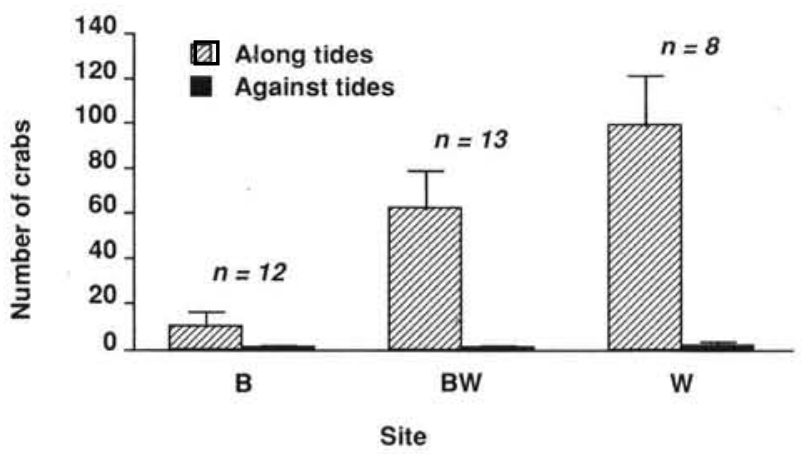

Fig. 2. Scopimera globosa. Number of crabs crossing a line of $50 \mathrm{~cm}$ length, placed in each area parallel to the tide line. B: lower site of the burrow area; BW: border of the burrow and water-saturated areas; W: upper site of the water-saturated area. Along tides: crabs which moved towards the water-saturated area after emergence or landwards before flood tides; against tides: crabs which moved landwards after emergence of the areas or towards the water-saturated area with the flood tide. Vertical bars represent standard errors 
Table 1. Organic nitrogen content $\left(\mathrm{mg} \mathrm{g}^{-1}\right.$ dry wt, average $\%$ $\pm \mathrm{SD}$ ) in the substratum in the burrow and water-saturated areas ( 5 samples from each plot)

\begin{tabular}{|lcc|}
\hline Month & Burrow area & Water-saturated area \\
\hline Jun & $0.44 \pm 0.05$ & $2.72 \pm 0.30$ \\
Jul & $0.38 \pm 0.06$ & $5.76 \pm 0.64$ \\
Aug & $0.34 \pm 0.03$ & $1.22 \pm 0.12$ \\
\hline
\end{tabular}

rated area on the next clear day. I counted 100 crabs moving to the lower site during a 10 min observation in the burrow area when the tide receded on July 8, following a rainy night.

\section{Diet quality}

The organic nitrogen content of the surface substratum in the water-saturated area was significantly higher than that in the burrow area $(F=30.62, \mathrm{df}=1, \mathrm{p}<0.0001$; Table 1), indicating that the quality of diet was better in the water-saturated area than in the burrow area.

\section{Time budget of behaviours}

Both male and female crabs in the water-saturated area spent more time foraging than those in the burrow area $(F=17.13, \mathrm{df}=2, \mathrm{p}<0.0001$ for males; $F=$ $42.14, \mathrm{df}=2, \mathrm{p}<0.0001$ for females after arcsine transformation; Table 2). Both male and female crabs in the burrow area where females extruded eggs spent more time on social interactions with other crabs than those in the water-saturated area $(F=3.55, \mathrm{df}=2, \mathrm{p}<0.05$ for males; $F=10.75, \mathrm{df}=2, \mathrm{p}<0.001$ for females; Table 2 ). Waving display was mostly conducted by burrow- holding males in the burrow area (Table 2). Ovigerous females, not observed here, stayed in the burrows (Henmi \& Kaneto 1989), which would reduce the average foraging time of burrow-holding females in the burrow area.

\section{Alternative mating behaviours}

Mating behaviour depended on the microhabitats ( $p<0.0001$, Fisher's exact probability test; Table 3 ). Of the 2 types of mating behaviour, UC, which involves post-copulatory guarding and guarantees the paternity of the male mate, was dominant in the burrow area. The UC female oviposited and incubated in the male's burrow (see Henmi \& Kaneto 1989, Koga et al. 1993). SC was extremely dominant in the water-saturated area where most crabs did not have burrows (Table 3).

The numbers of UC and SC observed per hour were 0.91 and 0.46 ( 0.78 and 0.23 during spring tides, 1.01 and 0.53 during mid tides, and 0.89 and 0.59 during neap tides) in the burrow area and 0.20 and 2.35 ( 0.25 and $1.75,0.12$ and 2.14 , and 0.40 and 4.00 during spring, mid and neap tides, respectively) in the watersaturated area. The number of matings observed did not differ significantly when compared to a lunar month $\left(\chi_{\mathrm{df}=2}^{2}=2.55, \mathrm{p}>0.2\right.$ for UC and SC separately in the burrow area, $\chi_{\mathrm{df}=2}^{2}=3.82, \mathrm{p}>0.1$ for $\mathrm{SC}$ in the water-saturated area, $\chi^{2}$-test), indicating that there is no lunar cycle of mating activity in Scopimera globosa.

\section{Sex ratios}

In the burrow area the density of males was significantly higher than that of nonovigerous females $(F=$

Table 2. Scopimera globosa. Behaviour budgets (average $\% \pm \mathrm{SD}$ ) of male and female crabs in the burrow and water-saturated areas. All crabs in the water-saturated area were burrowless. 'Waving display' is a behaviour for advertisement of vigor and probably for courtship like the fiddler crabs (see Crane 1975). 'Interactions' include premating and mating behaviours and struggles. 'Others' include cleaning of body, absorption of water, etc.

\begin{tabular}{|c|c|c|c|c|c|c|}
\hline \multirow[t]{3}{*}{ Behaviour } & \multicolumn{4}{|c|}{ BURROW AREA } & \multicolumn{2}{|c|}{ WATER-SATURATED AREA } \\
\hline & \multicolumn{2}{|c|}{ Male } & \multicolumn{2}{|c|}{ Female } & \multirow{2}{*}{$\begin{array}{c}\text { Male } \\
\text { Burrowless }\end{array}$} & \multirow{2}{*}{$\begin{array}{c}\text { Female } \\
\text { Burrowless }\end{array}$} \\
\hline & Burrow-holding & Burrowless & Burrow-holding & Burrowless & & \\
\hline Sample size: & 11 & 10 & 8 & 7 & 11 & 9 \\
\hline Foraging & $38.6 \pm 34.7$ & $16.0 \pm 21.8$ & $76.9 \pm 20.6$ & $13.4 \pm 23.9$ & $84.5 \pm 15.8$ & $95.6 \pm 4.2$ \\
\hline Resting & $5.9 \pm 13.7$ & $11.5 \pm 12.3$ & $0.8 \pm 1.0$ & $6.7 \pm 9.6$ & $1.1 \pm 1.8$ & $0.2 \pm 0.6$ \\
\hline Moving & $3.9 \pm 4.4$ & $48.4 \pm 18.7$ & $1.5 \pm 1.8$ & $28.8 \pm 22.8$ & $12.7 \pm 14.7$ & $3.5 \pm 4.2$ \\
\hline In burrow & $22.0 \pm 22.9$ & $6.3 \pm 6.7$ & $13.3 \pm 20.3$ & $12.0 \pm 7.7$ & $0.3 \pm 1.0$ & $0 \pm 0$ \\
\hline Digging & $1.8 \pm 5.4$ & $4.7 \pm 11.9$ & $1.8 \pm 5.1$ & $13.8 \pm 24.9$ & $0 \pm 0$ & $0 \pm 0$ \\
\hline Waving display & $18.0 \pm 23.3$ & $0.1 \pm 0.4$ & $0 \pm 0$ & $0.4 \pm 0.9$ & $0 \pm 0$ & $0 \pm 0$ \\
\hline Interactions & $4.4 \pm 5.8$ & $5.6 \pm 4.3$ & $3.1 \pm 7.3$ & $9.5 \pm 6.4$ & $1.3 \pm 1.7$ & $0.2 \pm 0.4$ \\
\hline Others & $5.4 \pm 11.3$ & $3.6 \pm 3.7$ & $2.6 \pm 5.6$ & $15.5 \pm 19.1$ & $0.1 \pm 0.4$ & $0.5 \pm 0.8$ \\
\hline
\end{tabular}


Table 3. Scopimera globosa. Number of alternative mating behaviours in the burrow and water-saturated area. UC: underground copulation; SC: surface copulation

\begin{tabular}{|ccc|}
\hline Behaviour & Burrow area & Water-saturated area \\
\hline UC & 40 & 3 \\
SC & 20 & 35 \\
\hline
\end{tabular}

122.42, df =1, $\mathrm{n}=174, \mathrm{p}<0.0001$, ANOVA; Fig. 1). In the water-saturated area, to the contrary, the density of males was significantly lower than that of nonovigerous females $(F=21.09$, df $=1, \mathrm{n}=218, \mathrm{p}<0.001$, ANOVA; Fig. 1); i.e. operational sex ratios were biased towards males in the burrow area and towards females in the water-saturated area (Fig. 3). Males copulating in the burrow area where females extruded eggs had an advantage over the ones in the water-saturated area because of the last-male precedence in sperm competition (Koga et al. 1993), which probably biased operational sex ratios in the burrow area towards males.

\section{Proportion of spent females}

Spent females emerged from the burrow area and moved to the water-saturated area during late June to September, with a slight time lag for the emergence of ovigerous females (Fig. 4, see also Fig. 1). The proportions of spent females to total nonovigerous females in the water-saturated area were higher than those in the burrow area from late June to early August (Fig. 4). The highest proportion of spent females in the watersaturated area in early July followed the highest density of ovigerous females in the burrow area in late June (Fig. 1b), indicating that ovigerous females in the burrow area moved to the water-saturated area after finishing incubation.

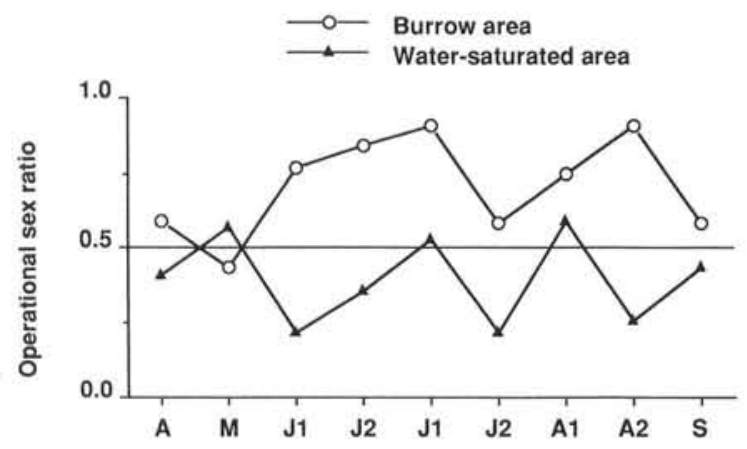

Fig. 3. Scopimera globosa. Ratio of total number of males to total number of nonovigerous females (operational sex ratio) in the burrow and water-saturated areas in and around the June-August reproductive season

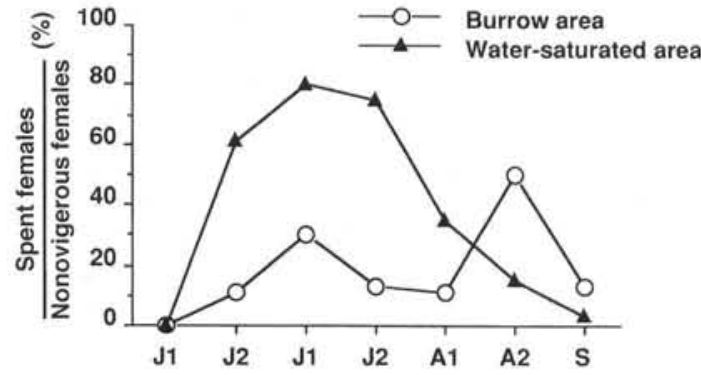

Fig. 4. Scopimera globosa. Proportion of spent females to nonovigerous females in the burrow and water-saturated areas

\section{Ripeness of females}

To show the correlation of female movements between microhabitats with female reproductive condition, RGWs of nonovigerous females were compared. RGW of nonovigerous nonspent females in the burrow area was significantly larger than that in the watersaturated area throughout the reproductive season $(F=$ 38.82, df $=1, \mathrm{n}=84, \mathrm{p}<0.0001$ for site $F=1.13$, df $=2$, $p>0.3$ for season, ANOVA; Fig. 5). Most spent females had very small gonads [average $\mathrm{RGW} \pm \mathrm{SD}(\%)=0.6 \pm$ $0.9, \mathrm{n}=30]$. Thus, unripe females stayed in the watersaturated area to forage for the next reproduction season. When they became ripe, they moved to the burrow area for oviposition and incubation (see also Fig. 1a).

\section{Conditions of male gonads and hepatopancreas}

Different from the trend in females, the relationship between male body condition and microhabitat use was unclear. There were no significant differences of RGWs or RHWs for males between the burrow and

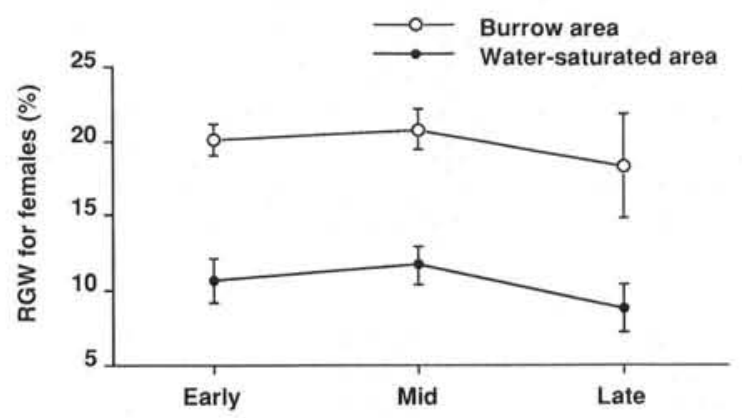

Fig. 5. Scopimera globosa. Relative gonad weight to body weight (RGW) for females in the burrow and water-saturated areas in early ( $\mathrm{n}=10$ and 10$)$, mid $(\mathrm{n}=25$ and 23$)$ and late $(n=$ 6 and 10) reproductive season. Vertical bars show standard errors 


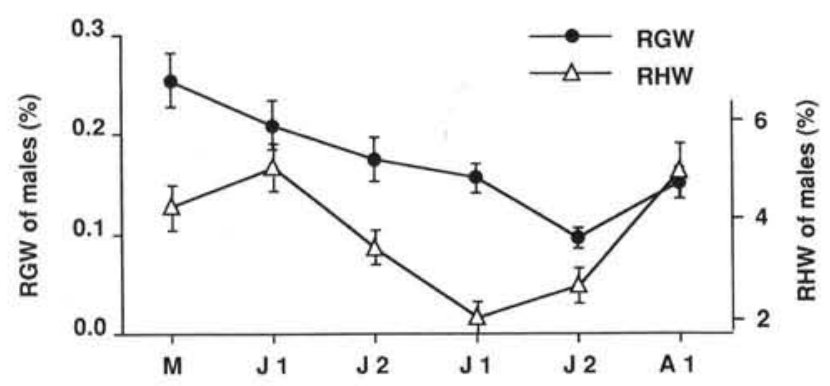

Fig. 6. Scopimera globosa. Relative gonad and hepatopancreas weight (RGW and RHW) for males (dry weight). Sample size in each plot was 20 (males in the burrow area + ones in the water-saturated area). Vertical bars show standard errors

water-saturated areas $(F=2.08, \mathrm{df}=1, \mathrm{n}=120, \mathrm{p}>0.1$; $F=2.25, \mathrm{df}=1, \mathrm{p}>0.1$, respectively). However, both RGWs and RHWs for males significantly decreased with time during the early and the mid reproductive season $(F=8.49, \mathrm{df}=5, \mathrm{n}=120, \mathrm{p}<0.001 ; F=8.61, \mathrm{df}=$ $3, \mathrm{n}=120, \mathrm{p}<0.001$, respectively; Fig. 6). Compared to females, only a small number of males stayed in the water-saturated area during the reproductive season (Fig. 1), because the males were no longer in the foraging area and thus had a lower intake of food, which resulted in smaller hepatopancreas. Since males in both the burrow and water-saturated areas were engaged in copulation (Table 3 ), male gonad weight decreased during the reproductive season (Fig. 6).

\section{Body size of crabs}

Females in the burrow area were generally larger than those in the water-saturated area during the reproductive season (Fig. $7 \mathrm{a}$ ), although there was no significant difference in the body size of females between the 2 microhabitats before the reproductive season (i.e. May). This and the fact that there were more ovigerous females in the burrow area than in the water-saturated area (Fig. 1a) suggest that large females stay in the burrow area with a higher proportion than small females did in spite of poor food conditions.

Males in the burrow area were significantly larger than those in the water-saturated area except from late June to late July, the peak of male population density in the burrow area and of the reproductive season (Fig. 7b, see also Fig. 1). That is, a large proportion of large (i.e. older) males stayed in the burrow area throughout the reproductive season in spite of poor food conditions. Only at the peak of reproductive season did small (i.e. young) males also appear in the burrow area. (a)

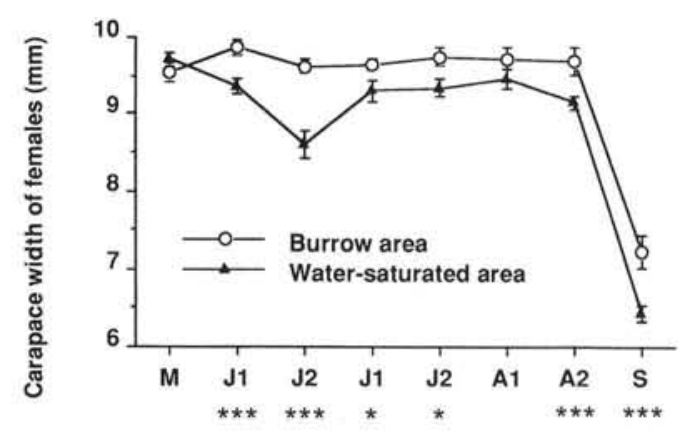

(b)

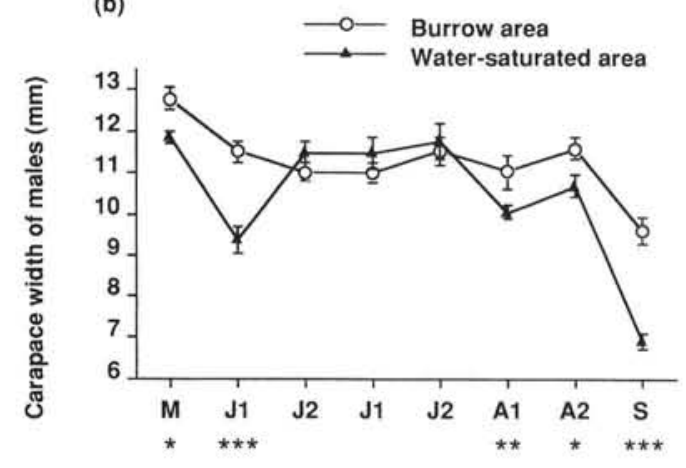

Fig. 7. Scopimera globosa. Carapace width of (a) female and (b) male crabs in the burrow and water-saturated areas. Vertical bars show standard errors. ${ }^{*} \mathrm{p}<0.05,{ }^{* \star} \mathrm{p}<0.01$, ${ }^{\star \star \star} p<0.005$. See Fig. 1 for sample size

\section{DISCUSSION}

\section{Sexual difference of movements in the two microhabitats}

Movements of Scopimera globosa between the 2 microhabitats and the difference in gonad weights of females between the habitats suggest that the burrow area is mainly the place for oviposition and incubation and that the water-saturated area is for foraging females during reproductive season (see also Henmi et al. 1993). The water-saturated area was suitable for accumulation of energy for reproduction because of a better quality of diet than in the burrow area (see also Murai et al. 1982, 1983). The crabs were usually in the burrow area and formed droves in the water-saturated area from late spring to late autumn (Wada 1981b). In this study, many females were found in the water-saturated area before and during the early reproductive season (May and early June). In contrast, around the peak of the reproductive season (late June and early July), many females were found in the burrow area and most of them were ovigerous, whereas there was only a small number of ovigerous females (all oviger- 
ous females in the water-saturated area only had eggs which would soon hatch) in the water-saturated area. Following the reproductive peak, most spent females moved to the water-saturated area. During the reproductive season gonad weights of nonovigerous nonspent females in the burrow area were higher than those in the water-saturated area. That is, most females spent their time in the water-saturated area before oviposition in order to enlarge their gonads and then moved to the burrow area when their gonads developed. They extruded eggs and incubated in the burrow area and returned to the water-saturated area just before or after the release of zoea. The spent females accumulated energy for the next reproduction season in the water-saturated area, where they obtained a high feeding efficiency due to the richness of nutrients and infrequent interactions with other crabs (see also Henmi 1989a, Henmi \& Kaneto 1989, Henmi et al. 1993).

In contrast, no differences in male body condition were detected between the microhabitats (see also Iwata et al. 1983). Instead, gonad and hepatopancreas weights of males decreased with time in the early to mid reproductive season. Many males left the watersaturated area for the burrow area early in the reproductive season. Lower numbers of males than females returned to the water-saturated area during the mid reproductive season.

One can predict when females leave the burrow area for the water-saturated area because ovigerous females return to the water-saturated area after the release of zoea. However, when males do so is unpredictable because it is unclear whether males in the burrow area return to the water-saturated area after only a single copulation or after multiple copulations. Copulation in the burrow area may assure the paternity of the eggs for mating males more than in the water-saturated area, because the sperm of the last male mate fertilizes most of the eggs extruded by a female (Koga et al. 1993, author's unpubl. data). Males which stay longer in the burrow area are expected to copulate with more females coming from the water-saturated area for oviposition, i.e. to raise reproductive success. Thus, although energy reserves of males gradually decreased during the early to mid reproductive season (when most males stayed in the burrow area), most males probably remained in the burrow area, rather than returning to the water-saturated area to forage.

\section{Comparison of movement patterns in ocypodid crabs}

Droves were also reported in Macrophthalmus japonicus (Henmi 1984, 1989a), Uca pugilator (Christy \& Salmon 1984) and $U$. vocans (Murai et al. 1982, 1983,
Nakasone et al. 1983). Both sexes of M. japonicus, $U$. vocans and nonreproductive crabs of $U$. pugilator leave the burrow area for the low tide line (watersaturated area) during ebb tide and return during flood tide. Sexually active males of $U$. pugilator possess their own burrows in the burrow area and court receptive females into their burrows to copulate during low tide (Christy \& Salmon 1984). Male $U$. vocans return to the burrow area earlier than females to take possession of burrows and court females coming back from the water-saturated area (Nakasone et al. 1983).

Wada (1981b) found that female Scopimera globosa moved to the water-saturated area during ebb tide and then landwards during flood tide. On their way to higher ground some of the females were physically forced into males' burrows for copulation. In the present study, most $S$. globosa which were active in the water-saturated area during low tides stayed in the water-saturated area or the area on the border of the burrow and water-saturated areas even during high tides. As the ripeness of the gonad was drastically different between females in the burrow and water-saturated areas, $S$. globosa probably moved in a manner different from other ocypodid species.

Although low numbers of crabs moved between the burrow and water-saturated area, sudden and intense rainfall caused crabs in the water-saturated area to move to the burrow area. Ono (1965) showed that Scopimera globosa has a low tolerance to low salinity. The intense rainfall makes temporary rain puddles of low salinity in ĺower sites during low tide periods. Thus, the crabs may move landwards to escape from the nearly freshwater puddles. If the weather improves on the day following a heavy rain, the crabs with high energetic demands return to the water-saturated area with rich diet. This may be the reason why the movements of many crabs from the burrow area to watersaturated area were often observed on 'fine' days (this study; see also Sugiyama 1961, Wada 1981b).

\section{Biased sex ratios associated with male mating tactics}

Surface copulations frequently occur in the watersaturated area. Mobile decalcified gonopore of unripe females in Scopimera globosa allow the females to copulate at all stages of reproduction (Henmi et al. 1993). This aspect produces a great chance for male $S$. globosa to copulate on the surface in the watersaturated area where many females are active on the surface. Some SC females may extrude eggs after their gonads become ripe without further copulation and then move to the burrow area for oviposition.

In spite of the great chance for SC by males in the water-saturated area, operational sex ratios during the 
reproductive season were considerably biased towards males in the burrow area while biased towards females in the water-saturated area. For females, the burrow area was the place for oviposition and incubation and the water-saturated area was for foraging. Matings with unripe females in the water-saturated area are not expected to result in high paternity for males because nonovigerous females are capable of multiple copulations for one brood (Wada 1981b, Henmi et al. 1993). In addition, the last male to mate is extremely dominant in sperm competition in this species (Koga et al. 1993, author's unpubl. data). Therefore, many males were in the burrow area during the reproductive season to participate in underground mating. Consequently, operational sex ratios were different between the microhabitats.

\section{Microhabitat use and life history strategy}

Henmi \& Kaneto (1989) showed the possibility that large females of Scopimera globosa extruded eggs twice a year (in the early and the late reproductive season) but that small females did only once (in the mid to late reproductive season). Older large females may be able to prepare for oviposition earlier than younger small females and to extrude a greater number of eggs because they live longer and have a large body, but they have little chance of reproduction in the next year (Henmi \& Kaneto 1989). In contrast, small females may not be able to prepare enough for oviposition in the early reproductive season. However, they may extrude many eggs in the next year when they become large. Small females likely stay in the water-saturated area except during a single reproduction, spending most time foraging (as opposed to reproducing) in order to grow and develop their gonads than large females do in the water-saturated area. Although large females generally stay in the water-saturated area, as small females do, they move to and stay in the burrow area during the second reproduction. Perhaps duration of stay in the burrow area for each female is determined by the number of ovipositions in a year (see Henmi $1989 \mathrm{~b}$ for incubation period of this species). Thus, large females which extrude 2 broods may stay approximately twice as long in the burrow area as small ones which extrude once, causing the difference in female body size between the 2 microhabitats.

A large proportion of large males stay in the burrow area throughout the reproductive season in spite of the poor quality of diet there. This is because they may have a greater chance to participate in reproduction in that year and less chance in the following year than small males. Small males, on the contrary, may have little chance of reproduction in that year because of their low competitive ability. Therefore they may stay in the water-saturated area to concentrate on growth, except during the peak of reproductive season. In spite of their low competitive ability, even small males may fertilize eggs in the peak of the reproductive season when a large number of females appear in the burrow area for oviposition. Tejedo (1992) suggested that smaller (younger) males of natterjack toads may be present in the breeding site less frequently because of energy limitations. Energetic constraints may affect the energy that should be allocated to growth, which is higher in younger small males than in older large males. Similar constraints to this may also arise in male Scopimera globosa, because the crabs in this species continue to grow during their lifetime, as do the natterjacks. Small males of $S$. globosa probably allocate more energy to growth than large males because of their present poor ability for competition and the great success in the future.

\section{Cause of movements in Scopimera globosa}

There are 3 hypotheses for the cause of forming droves in water-saturated area in Scopimera globosa: (1) the social interaction hypothesis (Sugiyama 1961, Ono 1965, Yamaguchi \& Tanaka 1974); (2) the water condition hypothesis (Wada 1981b); and (3) the energy requirement hypothesis (Iwata et al. 1983, Henmi et al. 1993). The first hypothesis predicts that droves are caused by the interactions between crabs under high population density in the burrow area. Crabs with low competitive ability (i.e. small ones) may be excluded from the burrow area after interactions when the population density in the burrow area is high. In contrast, they may remain there as well as crabs with high competitive ability (i.e. large ones) when the density is low. However, small males with poor competitive ability moved to and stayed in the burrow area along with large males only when many females moved to the burrow area for oviposition, causing the highest population density at that time. That is, the difference in body size of males between the 2 microhabitats was small when the population density in the burrow area was high, but large when the density there was low. This is exactly the opposite of what would be predicted by the first hypothesis. The second hypothesis predicts that the most sunshine and highest temperature induce highest population density in the water-saturated area. However, population density in the water-saturated area just before or at the beginning of the reproductive season (May to early June) was higher than when the surface substrate was severely hot and dry (late July to August). In addition, sudden intense rain, which makes 
temporary rain puddles of low salinity, forced crabs in the water-saturated area to move to the burrow area. If the weather improved on the day following heavy rain, they returned to the water-saturated area. The low salinity in the water-saturated area, not the dryness in the burrow area, may induce the temporary movements of the crabs between the 2 microhabitats. Thus, the second hypothesis does not explain the movements of this species either. In the present study, the microhabitats of $S$. globosa with a different nitrogen content in surface substrate were divided into the sites for reproduction (the burrow area) and foraging (the water-saturated area). Females with small gonads stayed in the water-saturated area until their gonads became large, and then moved to the burrow area for oviposition and incubation. After releasing zoea, the spent females returned to the water-saturated area to accumulate energy for the next brood extruded in that year or the next year. Many males stayed in the burrow area during the early to mid reproductive season to copulate with females with large gonads coming from the water-saturated area, although they stayed in the water-saturated area before the reproductive season. Gonad and hepatopancreas weight decreased during the early to mid reproductive season. Life history theory predicts for iteroparous species that young individuals invest more resources in growth than reproduction whilst old individuals invest more in reproduction than growth. Young small $S$. globosa of both sexes probably stayed longer in the foraging site than older large crabs, to allocate their energy to growth rather than reproduction. In contrast, large crabs which should allocate their whole energy to reproduction probably stayed longer in the site for reproduction. That is, individuals requiring high energy reserves for either reproduction or growth stayed in the water-saturated area with the rich diet. The results, therefore, support the third hypothesis and further suggest optimal foraging behaviour of the crabs under times of food constraint, in relation to their life history strategy.

Acknowledgements. I wish to express my sincere appreciation to M. Murai for encouragement throughout the study and critical comments on the manuscript and to Y. Henmi and $\mathrm{H}$. Matsuda for valuable comments on the manuscript. I also thank V. L. Smithern for reading the manuscript and 3 reviewers for critical suggestions and comments.

\section{LITERATURE CITED}

Andersson, M. (1994). Sexual selection. Princeton University Press, Princeton

Christy, J. H., Salmon, M. (1984). Ecology and evolution of mating systems of fiddler crabs (genus Uca). Biol. Rev. 59: 483-509
Crane, J. (1975). Fiddler crabs of the world. Ocypodidae: genus Uca. Princeton University Press, Princeton

Henmi, Y. (1984). The description of wandering behavior and its occurrence varying in different tidal areas in Macrophthalmus japonicus (De Haan) (Crustacea: Ocypodidae). J. exp. mar. Biol. Ecol. 84: 211-224

Henmi, Y. (1989a). Factors influencing drove formation and foraging efficiency in Macrophthalmus japonicus (De Haan) (Crustacea: Ocypodidae). J. exp. mar. Biol. Ecol. 131: $255-265$

Henmi, Y. (1989b). Reproductive ecology of three ocypodid crabs. II. Incubation sites and egg mortality. Ecol. Res. 4: 261-269

Henmi, Y., Kaneto, M. (1989). Reproductive ecology of three ocypodid crabs. I. The influence of activity differences on reproductive traits. Ecol. Res. 4: 17-29

Henmi, Y., Koga, T., Murai, M. (1993). Mating behavior of the sand bubbler crab Scopimera globosa. J. crust. Biol. 13: 736-744

Iwata, K., Arita, T., Iino, K. (1983). Seasonal changes in energy reserves of Scopimera globosa (Crustacea: Ocypodidae), with special reference to its wandering behaviour. Zool. Mag. 92: 306-316

Koga, T., Henmi, Y., Murai, M. (1993). Sperm competition and the assurance of underground copulation in the sandbubbler crab, Scopimera globosa (Brachyura: Ocypodidae). J. crust. Biol. 13: 134-137

Murai, M., Goshima, S., Nakasone, Y. (1982). Some behavioral characteristics related to food supply and soil texture of burrowing habitats observed on Uca vocans vocans and U. lactea perplexa. Mar. Biol. 66: 191-197

Murai, M., Goshima, S., Nakasone, Y. (1983). Adaptive droving behavior observed in the fiddler crab Uca vocans vocans. Mar. Biol. 76: 159-164

Nakasone, Y., Okamine, H., Asato, K. (1983). Ecology of the fiddler crab Uca vocans vocans (Linnaeus) (Decapoda: Ocypodidae). II. Relation between the mating system and the drove. Galaxea 2: 119-133

Ono, Y. (1965). On the ecological distribution of ocypodid crabs in the estuary. Mem. Fac. Sci., Kyushu Univ. 4: $1-60$

Salmon, M., Hyatt, G. W. (1983). Spatial and temporal aspects of reproduction in North Carolina fiddler crabs (Uca pugilator Bosc). J. exp. mar. Biol. Ecol. 70: 21-43

Sugiyama, Y. (1961). The social structure of a sand-crab, Scopimera globosa De Haan, with special reference to its population. Phys. Ecol. Japan 10: 10-17 (in Japanese with English summary)

Tejedo, M. (1992). Large male mating advantage in natterjack toads, Bufo calamita: sexual selection or energetic constraints? Anim. Behav. 44: 557-569

Wada, K. (1981a). Growth, breeding, and recruitment in Scopimera globosa and Ilyoplax pusillus (Crustacea: Ocypodidae) in the estuary of Waka River, middle Japan. Publ. Seto mar. Biol. Lab. 26: 243-259

Wada, K. (1981b). Wandering in Scopimera globosa (Crustacea: Ocypodidae). Publ. Seto mar. Biol. Lab. 26: 447-454

Yamaguchi, T., Noguchi, Y., Ogawara, N. (1979). Studies of the courtship behavior and copulation of the sand bubbler crab, Scopimera globosa. Publ. Amakusa mar. Biol. Lab. 5: 31-44

Yamaguchi, T., Tanaka, M. (1974). Studies on the ecology of a sand bubbler crab, Scopimera globosa De Haan (Decapoda: Ocypodidae). I. Seasonal variation of population structure. Jap. J. Ecol. 24: 165-174 (in Japanese with English summary) 